\title{
Short-Term Effect of Conservation Tillage on Carbon Pools under Rainfed Cropping Systems of Central India
}

\author{
Awanish Kumar ${ }^{1 *}$, Anusuiya Panda ${ }^{2}$, V.N. Mishra ${ }^{2}$ and L.K. Srivastava ${ }^{2}$ \\ ${ }^{1}$ ICAR-Indian Grassland and Fodder Research Institute, Jhansi, India \\ ${ }^{2}$ Indira Gandhi Krishi Vishwavidyalaya Raipur, Chhattisgarh, India \\ *Corresponding author
}

\begin{abstract}
A B S T R A C T
Short-term (after 3 crop cycle) field experiment was conducted to assess the effect of three tillage systems no tillage (NT), reduced tillage (RT) and conventional tillage (CT) and four crop rotations were selected, soybean $+\mathrm{P}$. pea $(\mathrm{S}+\mathrm{PP}, 2: 1)$, soybean- wheat $(\mathrm{S}-\mathrm{W})$, maize + P. pea $(\mathrm{M}+\mathrm{PP}, 1: 1)$ and maize- gram $(\mathrm{M}-\mathrm{G})$ with their residue management (residue

Keywords

Tillage system, Cropping system, Residue management, Vertisols, Soil organic fractions

Article Info

Accepted: 14 December 2017 Available Online: 10 January 2018 retained vs. burnt) on soil organic carbon fractions were study in a black soils (Vertisols) of Central India. Change in soil organic fractions influence in soil quality, health and carbon sequestration. Pools of soil organic matter (SOM) fractions (4 fractions) of carbon, very labile (VL), labile (L), less labile (LL) and non-labile (NL) return the status and composition of soil organic carbon at different $(0-5,5-15,15-30$ and 30-45 cm) depths and have implications for the change and retention of SOC. Our aims of study to determine how three tillage practices and four cropping systems (CS) with residue management, affected soil organic carbon after third crop cycle. The results revealed that RT $(0.42,0.19$ $\& 0.19 \%)$ was significantly the highest soil organic carbon followed by NT $(0.41,0.17 \&$ $0.17 \%)$ than CT $(0.35,0.13 \& 0.14 \%)$ especially, VLC, LC and LLC fractions in $0-5 \mathrm{~cm}$ depth and NLC fraction recorded the highest in NT $(0.46 \%)$ as compared to RT $(0.42 \%)$ than CT $(0.40 \%)$. However, in case of $5-15 \mathrm{~cm}$ depth NT was found significantly the highest organic carbon fraction (VL, L, LL \& NL) followed by RT than CT. The lower depths $(15-30$ and 30-45 cm) found NLC > VLC > LC similar trend but, LLC was higher than $15-30 \mathrm{~cm}$ depth respectively. The result reveled that S-W $(0.44 \%)$ and $\mathrm{M}-\mathrm{G}(0.42 \%)$ based cropping system have the highest SOC in RT than NT S-W $(0.43 \%)$ and M-G $(0.43$ $\%)$, and in CT, S+PP $(0.38 \%)$ and $\mathrm{M}+\mathrm{PP}(0.37 \%)$ was found higher SOC fraction.
\end{abstract}

\section{Introduction}

In developing countries, intensive agriculture has been popular since ancient times because of high population density and limited available land. Therefore, various traditional cultivation practices were developed to increasing crop productivity especially rice and wheat. Vertisols are heavy soils having high clay particles with high shrink-swell potential and have wide, deep cracks when dry condition. Globally, these soils contain about $2.5 \%$ of the total earth area. In India, Vertisols with vertic characteristics, covers about 72.9 Mha, constitute approximately $22.2 \%$ of the total geographical area of the country of which $30.1 \%$ area comes under the state of Madhya 
Pradesh, respectively, in Central India. Low soil organic matter (SOM) is one of the major constraints affecting the productivity of these soils. SOM is play vital role in soil agroecosystems and it's an important indicator soil fertility as well as crop productivity because of its very important role in soil physical, chemical and biological properties (Gregorich et al., 1994).

Conservation agricultural (CA) is one concept for natural resource conservation and mitigation of adverse climatic effects and higher profitability (Das et al., 2014). CA systems have been successfully developed for many different regions of the world. These systems, however, have not been widely adopted by farmers for political, social and cultural reasons. Through greater adoption of CA systems, there is one way of potential to SOC in the soil, which would: 1.) help mitigate greenhouse gas emissions contributing to global warming and 2.) reduced of SOC loss and decomposition, increase soil productivity and avoid further environmental damage from the unsustainable use of inversion tillage systems, which threaten water quality, reduce soil biodiversity, and erode soil around the world. This technology is (CA) achieving higher productivity in long run (Mishra et al., 2015 and Bhattacharyya et al., 2015). According to Chen et al., (2009) carbon input can be increased and decomposition decreased by adopting residue managements and using conservation tillage. Crop residues retained on the soil surface in conservation agriculture in general, serve a number of beneficial functions, including soil surface protection from erosion, enhancing infiltration (Bhattacharya et al., 2008) and cutting run-off rate, decreasing surface evaporation losses of water, moderating soil temperature (Benegas, 1998) and providing substrate for the activity of soil micro-organisms, and a source of SOC (Six et al., 1999). However, short- and medium-term conservation tillage complicated to identify changes in SOC because of high background $\mathrm{C}$ content and its temporal and spatial variability (Bosatta and Agren, 1994). Haynes, 2000 and Ghani et al., 2003 suggested that labile $\mathrm{C}$ is a sensitive indicators of SOC changes because labile $\mathrm{C}$ pools responding more faster for change to land use and soil managements are SOC. Long-term implementation of conservation agricultural practices also increases organic matter and nutrients accumulations in the topsoil (Seki et al., 2001). Lower soil temperatures and increased soil moisture contributes to slower rates of organic matter oxidation. In contrast, labile $\mathrm{C}$ pools an increase in organic matter is normally observed within the surface soil (0$10 \mathrm{~cm})$ which helps in better soil aggregation (Rhoton, 2000). Minimum tillage practices, including no-till (NT) and reduced tillage (RT), have received attention due to their ability to both reduce soil erosion and increase $\mathrm{C}$ sequestration in agricultural surface soils (Cole et al., 1997) by increasing aggregate stability. Alvarez (2005) reviewed the effect of nitrogen and no-tillage on soil organic carbon (SOC) from 137 sites, concluded that nitrogen fertilizer increased SOC but only when crop residue were retained. Furthermore, nitrogen fertilizer use in tropics resulted in no SOC sequestration while in the temperate regions; there was a trend towards increasing SOC sequestration. After 22 years of no-till, Dalal (1992) found that soil total nitrogen decreased with the period of cropping irrespective of the tillage practices in subtropical cereal cropping in Australia. Similarly, Dalal et al., (2011) reported that tillage effects on soil organic carbon and soil total nitrogen were small following 40 years of no-tillage in Vertisols of Queensland region. Crop residue and $\mathrm{N}$ fertilizer interactively increased SOC and total N stocks in $0-10 \mathrm{~cm}$ depth and cumulative stocks at 0 $20 \mathrm{~cm}$ and $0-30 \mathrm{~cm}$ depths. It was evident that crop residue retention increased SOC and soil 
total $\mathrm{N}$ only when $\mathrm{N}$ fertilisers was applied.

Hence, the present study was undertaken to find out to evaluate the conservation technology impact on $\mathrm{C}$ sequestration and to determine the labile pools of carbon in different $(0-5,5-15,15-30$ and $30-45 \mathrm{~cm})$ depths under different tillage (CT, RT \& NT) and major cropping systems (soybean $+\mathrm{P}$. pea $2: 1$, soybean- wheat, maize + P. pea $1: 1$ and maize- gram) of rainfed condition in Vertisols of Central India.

\section{Materials and Methods}

\section{Description of experimental site}

A field experiment was conducted after third crop cycle (end of rabi session) 2013-14 on a deep black soil (Vertisols, Iisohyperthermic Typic Haplustert) at the research cum experimental farm of Indian Institute of Soil Science, Bhopal, India $\left(23^{\circ} 18^{\prime} \mathrm{N}, 77^{\circ} 24^{\prime} \mathrm{E}\right.$, $485 \mathrm{~m}$ above mean sea level). The soils of experimental site, initial value was varied from organic carbon (0.64 to $0.46 \%)$, total organic carbon (1.05 to $0.80 \%)$. The textural composition, soil reaction $(\mathrm{pH}), \mathrm{EC}$ and organic pools (VLC, LC, LLC and NLC) of different depths (0-5, 5-15, 15-30 and 30-45 $\mathrm{cm})$ are given in Table 1 . The climate of the experimental field was a hot sub humid typea mean annual air temperature of $25^{\circ} \mathrm{C}$ with $1130 \mathrm{~mm}$ mean annual rainfall (receive 65$70 \%$ June to September month) and $1400 \mathrm{~mm}$ potential evapotranspiration. The weather conditions during cropping session are given in Figure 1.

The experiment had three treatments: conventional tillage (CT) with residue burning, reduce tillage (RT) with residue incorporation and no tillage (NT) with residue retained in soil surface. The treatments were arranged in split plot design with three replication and four cropping systems and size of plots $5 \times 10 \mathrm{~m}$. The CT plots have done deep summer ploughing after residue burning and 3 to 4 pass tine cultivator followed by sowing in kharif and rabi crops. The RT treatment has done one pass duck foot tine cultivator and sowing through zero till seed drill in kharif and rabi crops and NT has done without any tillage operation followed by sowing by zero till seed drill in kharif and rabi crops.

\section{Soil sampling and processing}

Soil samples were collected from four depths $(0-5,5-15,15-30$ and $30-45 \mathrm{~cm})$ within the CT, RT and NT tillage treatments in April 2014. Soil samples was air dried in a screen house shed and grained with wooden mortal and petal and passed through a 2 and $0.25 \mathrm{~mm}$ sieve for organic carbon and TOC analysis.

\section{Analytical methods for soil analysis}

The soil samples were analyzed for total organic $\mathrm{C}$ using a VCSH model in original biomass and sample were determined by dry combustion method using Shimadzu TOC analyzer. (Shimadzu, 5000 VA).The total organic carbon in different depths of each treatment was calculated using the equivalent mass basis. Organic carbon content of the soil sample was determined following the wet digestion method (Walkley and Black, 1934). The organic carbon pool in soils was determined by (Chan et. al., 2001). The determination of oxidizable carbon was repeated using 5 and $10 \mathrm{ml}$ of concentrated sulphuric acid instead of the $20 \mathrm{ml}$ specified by Walkley and Black (1934). The resulting three acid-aqueous solution ratios of $0.5: 1,1: 1$ and 2:1 (which corresponded respectively to $12 \mathrm{~N}, 18 \mathrm{~N}$, and $24 \mathrm{~N}$ of $\mathrm{H}_{2} \mathrm{SO}_{4}$ ) allowed comparison of oxidizable organic carbon extracted under increasing oxidizing conditions (Walkley, 1947). The amount of oxidizible organic carbon determined using 5 , 10 , and $20 \mathrm{ml}$ of concentrated sulphuric acid 
when compared with total carbon concentration allowed separation of total organic carbon into four fractions viz. (very labile carbon, labile carbon, less labile carbon, non-labile carbon fraction of carbon) of decreasing oxidizability. Organic carbon percentage was calculated from the following formula:

$\%$ OC $=10 \times \frac{\text { Blank }- \text { Sample reading }}{\text { Blank reading } \times \text { wt. of sample }} \times 0.003 \times 100$

\section{Statistical analysis}

The organic pools mean data were analysed using two way analysis of variance (ANOVA) technique following the split plot design. The data analysis was done by the using with SPSS windows, version 11.0. The significance of the treatment effect was determined using $F$-test, and to compare the significance difference between two treatments, least significance difference (LSD) was estimated at $P<0.05$.

\section{Results and Discussion}

\section{Soil organic carbon concentration (SOC)}

Mean data of soil organic carbon (SOC \%) concentration value after third crop cycles for CT, RT and NT shown in Table 2. In general, surface layer $(0-5 \mathrm{~cm})$ recorded higher SOC concentration compared to lower soil. McCarty et al., 1998 and Hati et al., 2014 concluded that CT particularly NT leads to higher concentration of SOC in the top layer of the soil $(0-5 \mathrm{~cm})$ and alters its distribution within the soil profile. The differences in SOC concentration between tillage treatment were highest in the upper most soil layer where they were ranked as follows: RT > NT > CT similar results found (Chan et al., 2009; Neugschwandtner et al., 2014). Irrespective of soil depths, higher SOC concentration was recorded under reduced tillage (RT) compared to no- tillage (NT) and conventional tillage
(CT) practices. It has been widely established that soils under long term NT and RT systems generally contain higher amounts of SOC concentration in the soil surface than CT (Freibauer et al., 2004; Conant et al., 2007; Thomas et al., 2007; Lopez-Fando and Pardo, 2009; Bhattacharyya et al., 2009). It is also inferred that SOC concentration decreased with increasing soil depth. Among the cropping systems compared, soybean + P. pea $\mathrm{S}+\mathrm{PP}$ and $\mathrm{M}-\mathrm{G}$ was recorded significantly higher OC concentration across the tillage in 0-5 cm depth, Das et al., 2013 found that cotton based cropping system had the highest root biomass addition in soil followed by maize based cropping systems. (Bhattacharyya et al., 2012) reported that in the Indian Himalayas, a reduction in tillage intensity led to a significantly larger SOC accumulation in the surface soil layer $(0-5 \mathrm{~cm})$, but not in the 5 - to $15-\mathrm{cm}$ soil layer after $6 \mathrm{yr}$ of cropping. The data show almost similar trend was observed under in 5-15 cm depth. SOC data of 15-30 and 30-45 cm indicated that $M-G$ and soybean-wheat (S-W) cropping system recorded significantly higher value compared to other systems. There was accumulating $\mathrm{C}$ concentration over the initial soil value (Table 1). It is clear from the data that the SOC content under RT and NT is significantly higher than CT after 3 crop-cycles. SalinasDarcia et al., 1997 was reported that increase of SOC concentration in RT systems may make these systems more sustainable over the long term as thereby $\mathrm{CO}_{2}$ is sequestered; a global data analysis indicated that carbon sequestration rates peak in 5 to 10 years with a change from MP to NT and SOC reaching a new equilibrium in 15 to 20 years (West and Post, 2002).

The soil biological property most affected by tillage is SOC concentration (Doran, 1980). Crop residues are precursors of the SOC pool, and returning more crop residues to the soil is associated with an increase in SOC 
concentration (Dolan et al., 2006). The effects of conservation tillage on SOC accumulation may vary with the amount and characteristics of residues returned to soil. Moreover, during tillage a redistribution of the soil organic matter takes place. Small changes in soil organic carbon can influence the stability of macro-aggregates. Carter (1992) found a close linear relationship between organic carbon and MWD.

In the current investigation, SOC data revealed that tillage practices were significant difference similar result was found Bhattacharyya et al., 2012. Cropping system and interaction between tillage and cropping system did nothave showed any significant effect on SOC content. It is clear from the data that the SOC concentration under RT is significantly higher than CT after four years of crop-cycle. However, conventional tillage system resulted in reduction in SOC over initial $(0.64 \%)$ value, whereas the SOC content under reduced tillage and no tillage after third crop cycle is maintained / buffered to its initial value. It is evident from the perusal of data that to bring significant changes in SOC under tillage system it requires a long term continuous residue addition coupled with minimum disturbances in soil. Similarly, no-tillage farming systems usually help to maintain soil organic matter (SOM) and aggregate stability (Rhoton, 2000). The year-round NT management practice was very effective for SOC sequestration in a rainfed lentil-finger millet rotation system (net gain in SOC storage was about $0.37 \mathrm{Mg}$ $\mathrm{ha}^{-1} \mathrm{yr}^{-1}$ in the $0-15 \mathrm{~cm}$ soil layer.

\section{Total Organic Carbon (TOC)}

The conservation agriculture (CA) practices had significant effect on total organic carbon (TOC \%) concentration after third crop cycles for different soil depths (Fig. 1). In general, surface layer $(0-5 \mathrm{~cm})$ recorded higher TOC compared to lower soil depths. Zanatta et al., 2007 concluded conservation tillage specially NT produce a less oxidative environment than $\mathrm{CT}$ and resulted in SOC accumulation, mainly in the $0-5 \mathrm{~cm}$ soil layer, at rates related to the addition of crop residues, which were increased by legume cover crops and $\mathrm{N}$ fertilization and the SOC accumulation rates peaked during the first years $\left(5^{\text {th }}\right.$ to $\left.9^{\text {th }}\right)$ after the adoption of the management practices and decreased exponentially over time, including that conservation soil management was a short-term strategy for atmospheric C mitigation. The adoption of no tillage (NT) in subtropical Brazilian soil has been lead to soil organic carbon accumulation in the $0-20 \mathrm{~cm}$ layer (Bayer et al., 2006). The results indicating that NT soils can acts as an atmospheric $\mathrm{C}$ sink. The less oxidative environment and the physical protection mechanism imparted by the stable aggregates of NT soils reduce soil organic matter mineralization rates (Gregorich et al., 1995; Feller and Beare, 1997; Six et al., 1999; Zanatta et al., 2007) and allow SOC accumulation. The differences in TOC accumulation between tillage treatment were highest in the upper most soil layer where they were ranked as follows: NT > RT > CT similar results found (Zanatta et al., 2007). Irrespective of soil depths, higher TOC accumulation was recorded under no tillage (NT) compared to reduced tillage (RT) than conventional tillage (CT) practices. Besides the adoption of reduced tillage (RT) practices, the cultivation of crops and cover crops (especially legumes) with high potential for Cbiomass addition is another prerequisite for SOC accumulation (Burle et al., 1997; Sisti et al., 2004). Diekow et al., 2005;Bayer et al., 2006 was observed that soils subjected to NT management for long period under lowaddition cropping systems did not accumulate SOC, although NT legume-based cropping systems showed, SOC accumulation rates higher than RT and CT. The accumulation of 
SOC on land (especially NT) is considered to be the result of different interacting factors, such as occurs in standing biomass in soil (e.g., crop residue, roots and microorganisms), recalcitrant organic matter in surface soil (e.g., humus), and inorganic $\mathrm{C}$ in subsoil (e.g., carbonates). The no tillage (NT) was significantly higher TOC content than conventional tillage (CT) in $0-5,15-30$ and $30-45 \mathrm{~cm}$ depth but $5-15 \mathrm{~cm}$ depth did not has showed significant effect Patihar et al., 2016 was reported that long- term CA practices had significant effect on soil organic content of different soil layer. Under $30-45 \mathrm{~cm}$ depth TOC content was found that significant different between the CS in third crop cycle where as other depth was found not significant difference.Among the cropping systems compared, S+PP and maize+ p. pea $(\mathrm{M}+\mathrm{PP}$, 1:1) recorded significantly higher TOC in CT system, S+PP and S-W rotation in RT and $\mathrm{S}+\mathrm{W}$ and $\mathrm{M}+\mathrm{G}$ in NT cropping systems. (Bhattacharya et al., 2015) reported thateffect of CA practices on soil organic carbon accumulation and crop productivity under a rice-wheat cropping system in the western
Indo-Gangetic Plains, allconservation agriculture (CA) plots had significantly higher gain (over initial value) in total SOC than that in TPR-CTW and TPR-ZTW treatments in the $0-15 \mathrm{~cm}$ layer and the gain in total SOC in the plots under MBR + DSR- ZTW + RR-ZTMB was significantly higher than all CA plots, despite having similar total SOC stocks.

The data show almost similar trend was observed under all depths. It is clear from the data that the TOC content under NT and RT is significantly higher than $\mathrm{CT}$ after third years of crop-cycle. Salinas-Darcia et al., 1997 was reported that increase of SOC content in NT \& RT systems may make these systems more sustainable over the long-term as thereby $\mathrm{CO}_{2}$ is sequestered; a global data analysis indicated that carbon sequestration rates peak in 5 to 10 years with a change from MP to NT and SOC reaching a new equilibrium in 15 to 20 years (West and Post, 2002). The interaction between tillage ( $\mathrm{T}$ ) and cropping systems (CS) ware showed significant difference in 15-30 $\mathrm{cm}$.

Fig.1 Effect of Conservation tillage in different cropping systems in TOC (\%) after 3 crop cycle in different depths

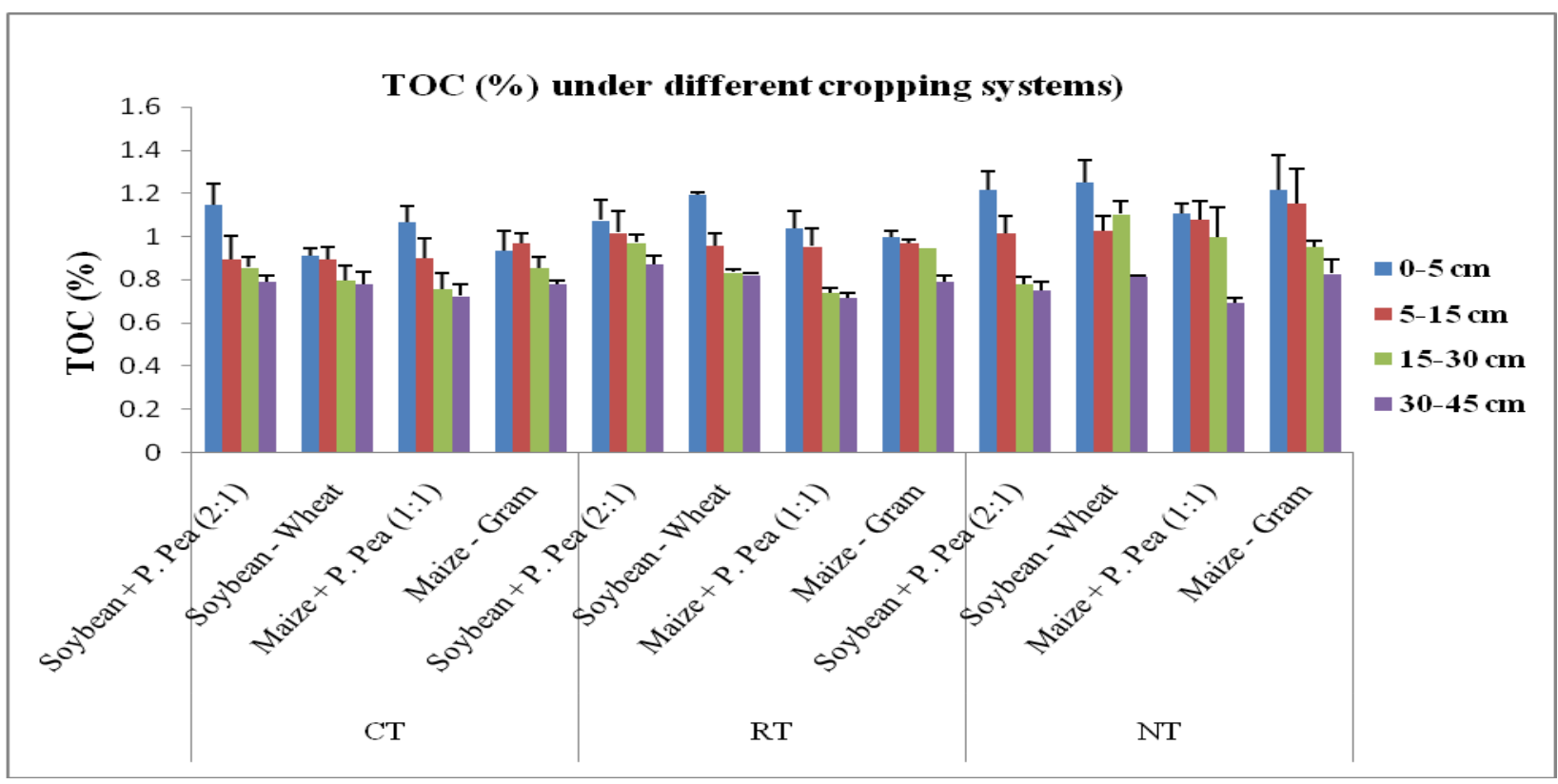


Fig.2 Effect of Conservation tillage in different cropping systems in soil organic pools (\%) after 3 crop cycle in $0-5 \mathrm{~cm}$ depth

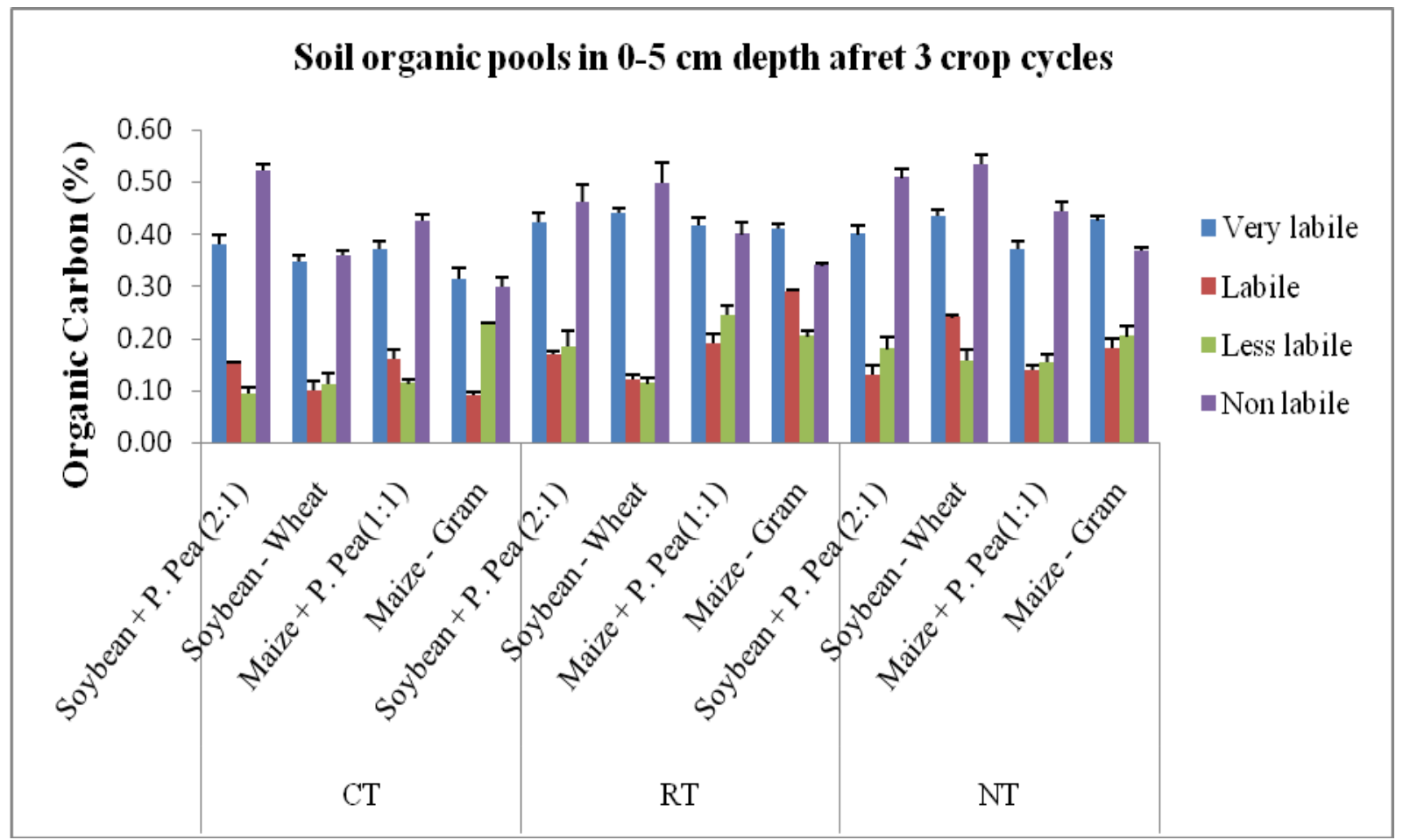

Fig.3 Effect of Conservation tillage in different cropping systems in soil organic pools (\%) after 3 crop cycle in $5-15 \mathrm{~cm}$ depth

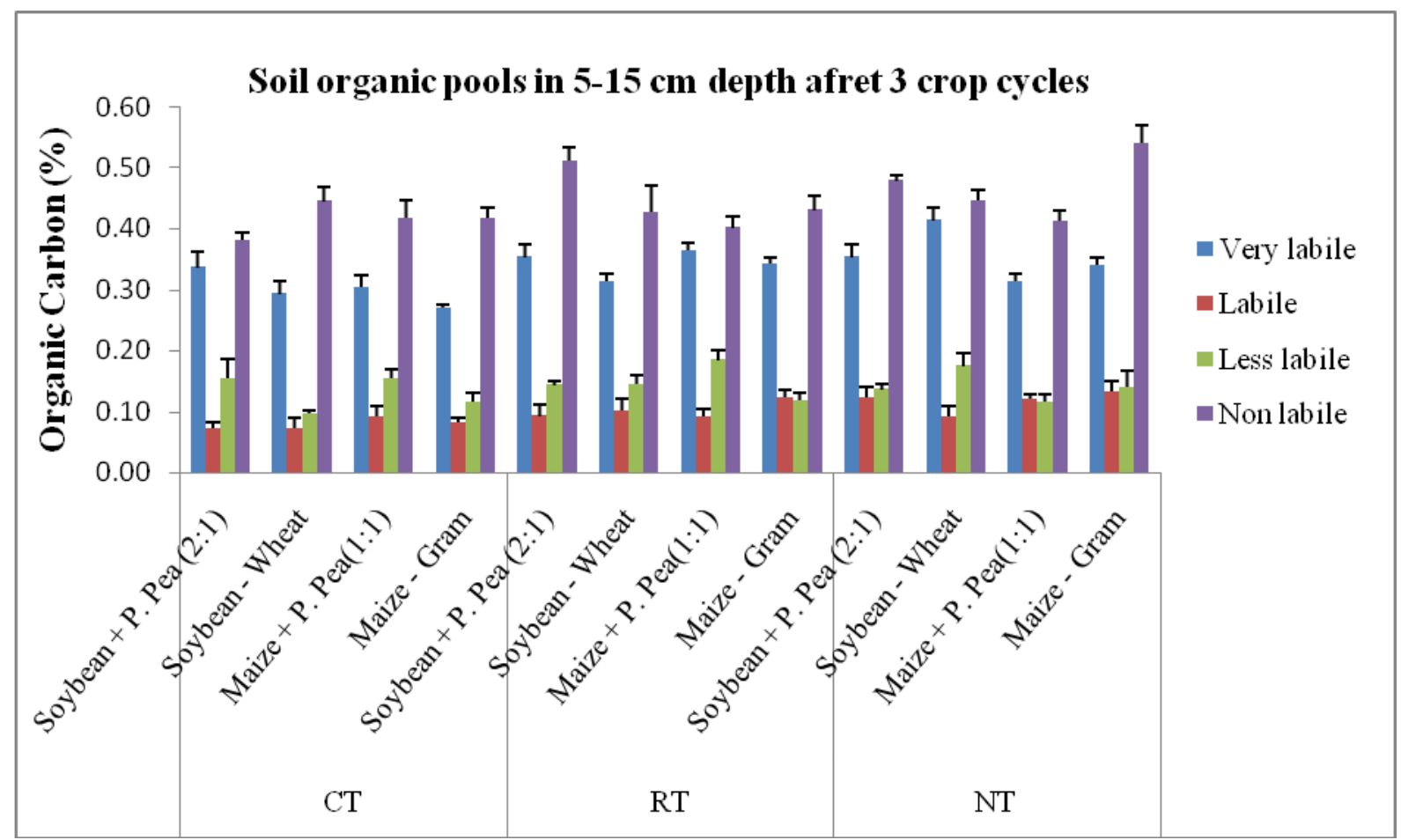


Fig.4 Effect of Conservation tillage in different cropping systems in soil organic pools (\%) after 3 crop cycle in $15-30 \mathrm{~cm}$ depth

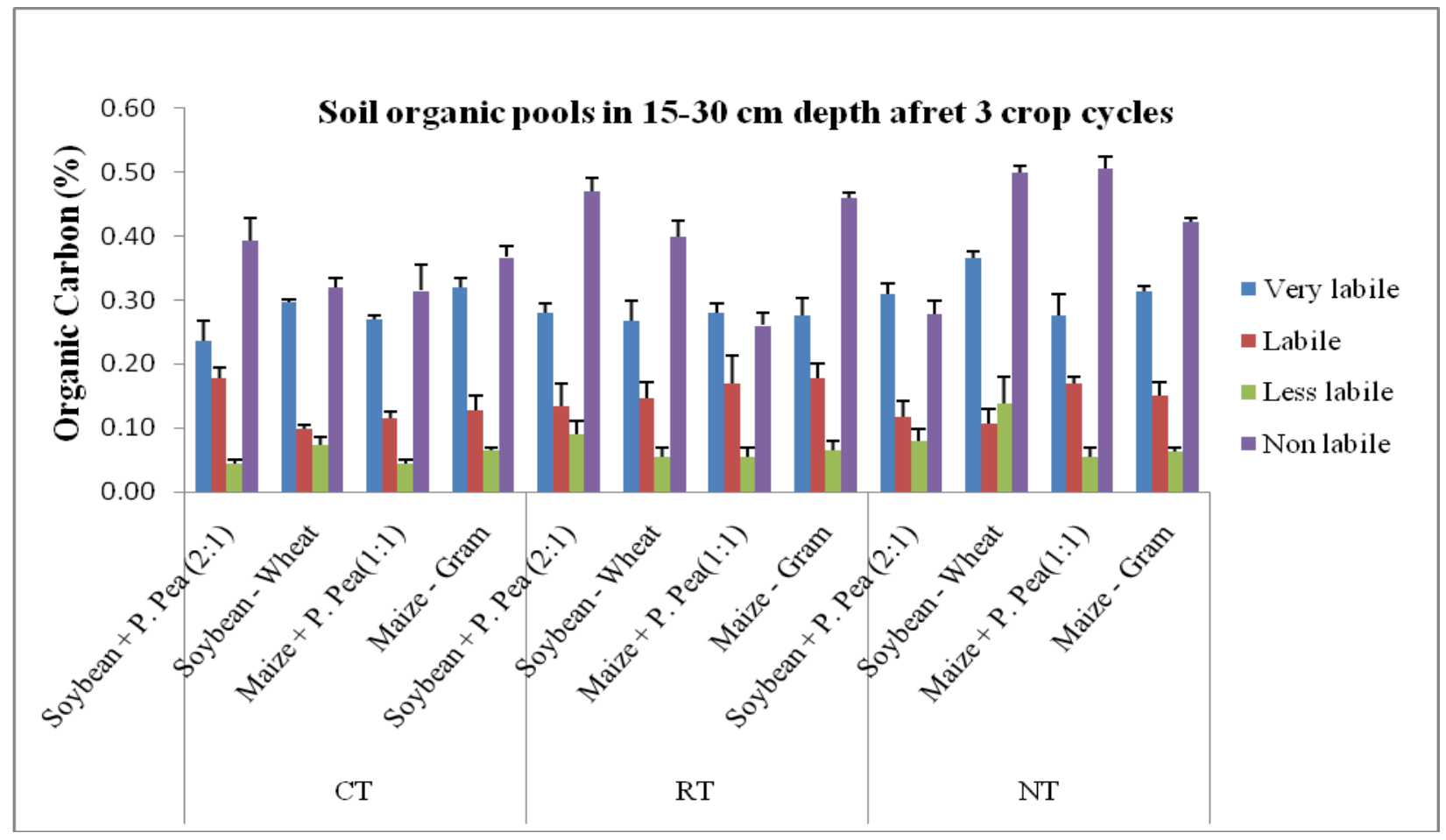

Fig.5 Effect of Conservation tillage in different cropping systems in soil organic pools (\%) after 3 crop cycle in $30-45 \mathrm{~cm}$ depth

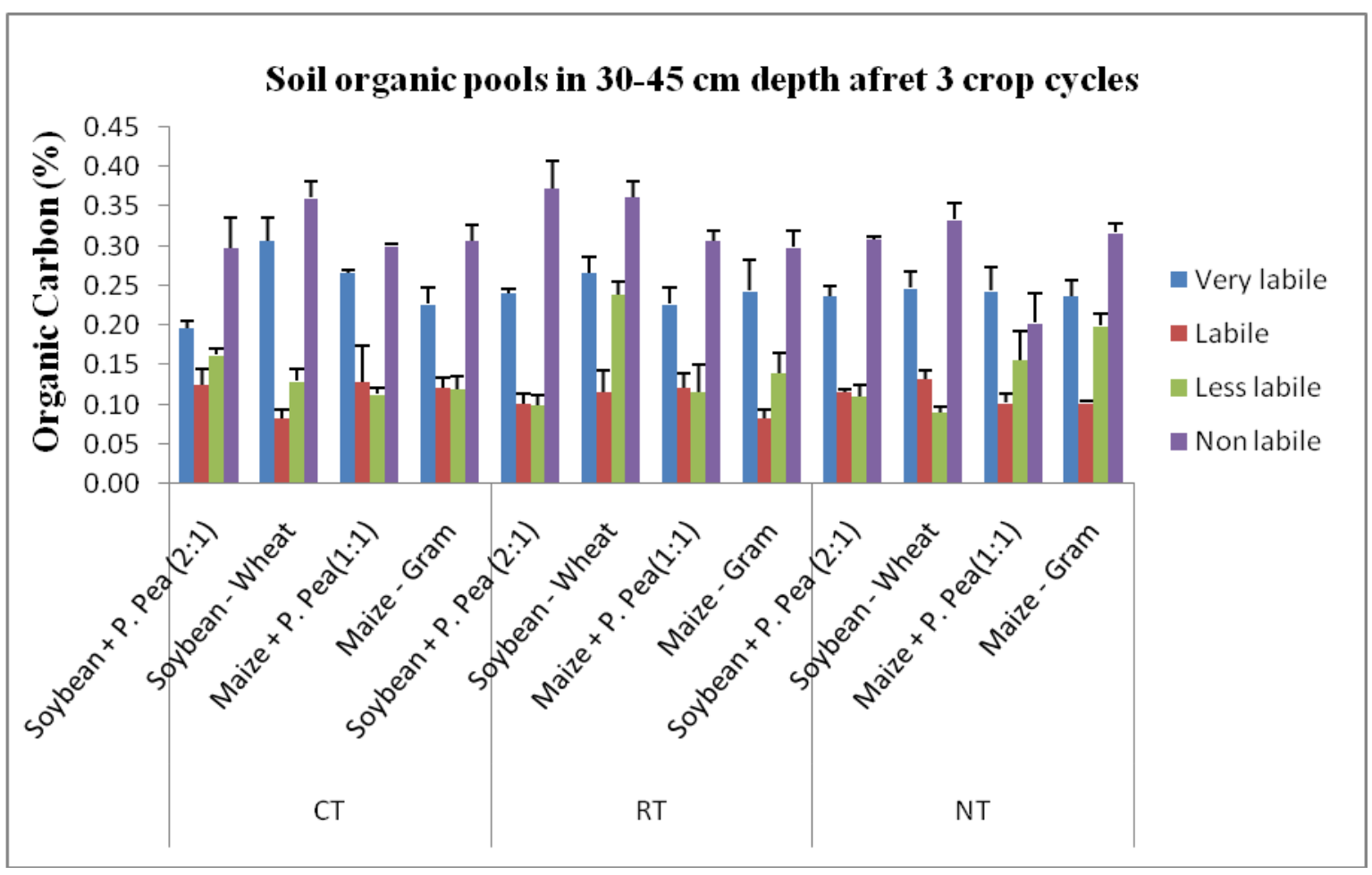


Table.1 Initial status (session, 2011-12) of soil properties at experimental site

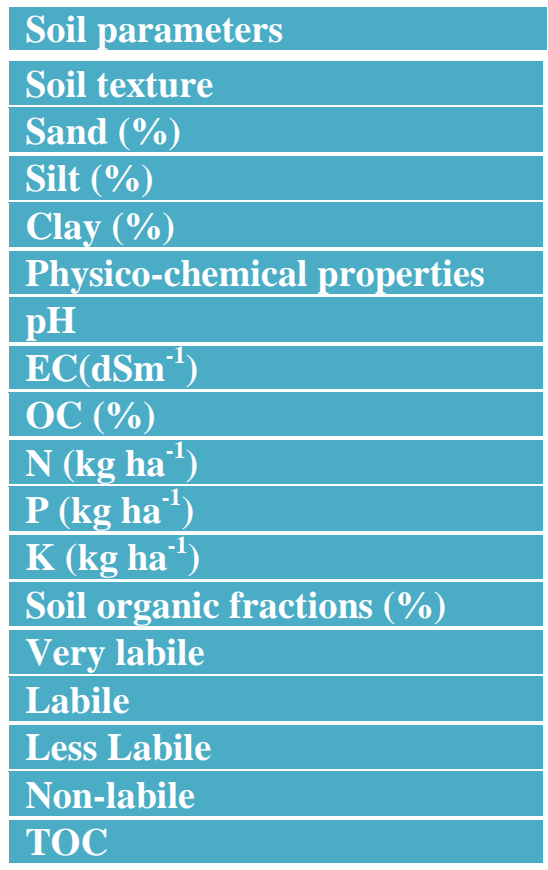

\begin{tabular}{|c|c|c|c|}
\hline \multicolumn{4}{|c|}{ Value } \\
\hline \multicolumn{4}{|c|}{ Particle size distribution } \\
\hline \multicolumn{2}{|c|}{22} & \multicolumn{2}{|c|}{ Clayey in Texture } \\
\hline \multicolumn{2}{|c|}{20} & & \\
\hline \multicolumn{2}{|c|}{58} & & \\
\hline $0-5 \mathrm{~cm}$ & $5-15 \mathrm{~cm}$ & $15-30 \mathrm{~cm}$ & $30-45 \mathrm{~cm}$ \\
\hline 8.16 & 8.17 & 8.17 & 8.18 \\
\hline 0.16 & 0.14 & 0.15 & 0.13 \\
\hline 0.64 & 0.54 & 0.52 & 0.46 \\
\hline \multicolumn{2}{|c|}{256.8} & \multicolumn{2}{|c|}{227.9} \\
\hline 22.46 & 16.48 & 14.85 & 16.63 \\
\hline 582.28 & 569.46 & 519.06 & 492.92 \\
\hline \multicolumn{4}{|c|}{$0-5 \mathrm{~cm} \mathrm{5-15} \mathrm{cm} 15-30 \mathrm{~cm} 30-45 \mathrm{~cm}$} \\
\hline 0.45 & 0.40 & 0.39 & 0.41 \\
\hline 0.12 & 0.10 & 0.06 & 0.05 \\
\hline 0.08 & 0.09 & 0.10 & 0.06 \\
\hline 0.74 & 0.63 & 0.61 & 0.54 \\
\hline 1.05 & 0.94 & 0.88 & 0.80 \\
\hline
\end{tabular}

Table.2 Effect of tillage and cropping system on soil organic carbon (\%) concentration in postharvest soils after 3 crop cycles in different depths

\begin{tabular}{|c|c|c|c|c|c|}
\hline \multirow{3}{*}{ Tillage (T) } & \multirow{3}{*}{ Cropping System (CS) } & \multirow{2}{*}{\multicolumn{4}{|c|}{ Organic Carbon (\%) }} \\
\hline & & & & & \\
\hline & & $0-5 \mathrm{~cm}$ & $5-15 \mathrm{~cm}$ & $15-30 \mathrm{~cm}$ & $30-45 \mathrm{~cm}$ \\
\hline \multirow[t]{5}{*}{ CT } & Soybean + P. Pea (2:1) & 0.64 & 0.55 & 0.47 & 0.45 \\
\hline & Soybean - Wheat & 0.59 & 0.48 & 0.48 & 0.42 \\
\hline & Maize + P. Pea(1:1) & 0.61 & 0.52 & 0.48 & 0.44 \\
\hline & Maize - Gram & 0.64 & 0.54 & 0.50 & 0.44 \\
\hline & Mean & 0.62 & 0.52 & 0.48 & 0.44 \\
\hline \multirow[t]{5}{*}{ RT } & Soybean + P. Pea (2:1) & 0.68 & 0.58 & 0.51 & 0.45 \\
\hline & Soybean - Wheat & 0.66 & 0.53 & 0.54 & 0.46 \\
\hline & Maize + P. Pea(1:1) & 0.67 & 0.60 & 0.56 & 0.45 \\
\hline & Maize - Gram & 0.67 & 0.55 & 0.51 & 0.49 \\
\hline & Mean & 0.67 & 0.57 & 0.53 & 0.46 \\
\hline \multirow[t]{5}{*}{ NT } & Soybean + P. Pea (2:1) & 0.66 & 0.59 & 0.53 & 0.47 \\
\hline & Soybean - Wheat & 0.66 & 0.56 & 0.52 & 0.49 \\
\hline & Maize + P. Pea(1:1) & 0.63 & 0.58 & 0.49 & 0.48 \\
\hline & Maize - Gram & 0.68 & 0.59 & 0.53 & 0.47 \\
\hline & Mean & 0.66 & 0.58 & 0.52 & 0.48 \\
\hline \multirow[t]{3}{*}{ LSD $(P<0.05)$} & $\mathrm{T}$ & 0.003 & 0.002 & 0.001 & 0.02 \\
\hline & CS & NS & NS & NS & NS \\
\hline & TXCS & NS & NS & NS & NS \\
\hline
\end{tabular}


Table.3 Effect of tillage and cropping systems soil organic carbon fractions (Pools) concentration in post-harvest soils after 3 crop cycles in different depths

\begin{tabular}{|c|c|c|c|c|c|c|c|c|c|c|c|c|c|c|c|c|c|}
\hline \multirow{3}{*}{$\begin{array}{c}\text { Tillage } \\
\text { (T) }\end{array}$} & \multirow{3}{*}{$\begin{array}{l}\text { Cropping System } \\
\text { (CS) }\end{array}$} & \multicolumn{16}{|c|}{ Soil Organic Pools After 3 Crop Cycles } \\
\hline & & \multicolumn{4}{|c|}{$0-5 \mathrm{~cm}$} & \multicolumn{4}{|c|}{$5-15 \mathrm{~cm}$} & \multicolumn{4}{|c|}{$15-30 \mathrm{~cm}$} & \multicolumn{4}{|c|}{$30-45 \mathrm{~cm}$} \\
\hline & & VL & $\mathbf{L}$ & $\mathbf{L L}$ & NL & VL & $\mathbf{L}$ & $\mathbf{L L}$ & NL & VL & $\mathbf{L}$ & $\mathbf{L L}$ & NL & VL & $\mathbf{L}$ & $\mathbf{L L}$ & NL \\
\hline \multirow[t]{5}{*}{ CT } & $\begin{array}{l}\text { Soybean + P. } \\
\text { Pea }(2: 1)\end{array}$ & 0.38 & 0.15 & 0.09 & 0.52 & 0.34 & 0.07 & 0.15 & 0.38 & 0.24 & 0.18 & 0.04 & 0.39 & 0.20 & 0.13 & 0.16 & 0.30 \\
\hline & Soybean - Wheat & 0.35 & 0.10 & 0.11 & 0.36 & 0.29 & 0.07 & 0.10 & 0.45 & 0.30 & 0.10 & 0.07 & 0.32 & 0.31 & 0.08 & 0.13 & 0.36 \\
\hline & Maize + P. Pea(1:1) & 0.37 & 0.16 & 0.11 & 0.42 & 0.30 & 0.09 & 0.15 & 0.42 & 0.27 & 0.11 & 0.04 & 0.31 & 0.27 & 0.13 & 0.11 & 0.30 \\
\hline & Maize - Gram & 0.31 & 0.09 & 0.23 & 0.30 & 0.27 & 0.08 & 0.12 & 0.42 & 0.32 & 0.13 & 0.06 & 0.37 & 0.23 & 0.12 & 0.12 & 0.31 \\
\hline & Mean & 0.35 & 0.13 & 0.14 & 0.40 & 0.30 & 0.08 & 0.13 & 0.42 & 0.28 & 0.13 & 0.06 & 0.35 & 0.25 & 0.11 & 0.13 & 0.32 \\
\hline \multirow[t]{5}{*}{ RT } & $\begin{array}{l}\text { Soybean + P. Pea } \\
(2: 1)\end{array}$ & 0.42 & 0.17 & 0.18 & 0.46 & 0.35 & 0.09 & 0.14 & 0.51 & 0.28 & 0.13 & 0.09 & 0.47 & 0.24 & 0.10 & 0.10 & 0.37 \\
\hline & Soybean - Wheat & 0.44 & 0.12 & 0.11 & 0.50 & 0.31 & 0.10 & 0.14 & 0.43 & 0.27 & 0.15 & 0.05 & 0.40 & 0.27 & 0.12 & 0.24 & 0.36 \\
\hline & Maize + P. Pea(1:1) & 0.42 & 0.19 & 0.24 & 0.40 & 0.36 & 0.09 & 0.18 & 0.40 & 0.28 & 0.17 & 0.05 & 0.26 & 0.23 & 0.12 & 0.11 & 0.31 \\
\hline & Maize - Gram & 0.41 & 0.29 & 0.20 & 0.34 & 0.34 & 0.12 & 0.12 & 0.43 & 0.28 & 0.18 & 0.06 & 0.46 & 0.24 & 0.08 & 0.14 & 0.30 \\
\hline & Mean & 0.42 & 0.19 & 0.19 & 0.42 & 0.34 & 0.10 & 0.15 & 0.44 & 0.28 & 0.16 & 0.07 & 0.40 & 0.24 & 0.11 & 0.15 & 0.33 \\
\hline \multirow[t]{5}{*}{ NT } & $\begin{array}{l}\text { Soybean + P. Pea } \\
(2: 1)\end{array}$ & 0.40 & 0.13 & 0.18 & 0.51 & 0.35 & 0.12 & 0.14 & 0.48 & 0.31 & 0.12 & 0.08 & 0.28 & 0.24 & 0.11 & 0.11 & 0.31 \\
\hline & Soybean - Wheat & 0.43 & 0.24 & 0.16 & 0.53 & 0.41 & 0.09 & 0.17 & 0.45 & 0.37 & 0.11 & 0.14 & 0.50 & 0.25 & 0.13 & 0.09 & 0.33 \\
\hline & Maize + P. Pea(1:1) & 0.37 & 0.14 & 0.15 & 0.44 & 0.31 & 0.12 & 0.12 & 0.41 & 0.28 & 0.17 & 0.05 & 0.51 & 0.24 & 0.10 & 0.16 & 0.20 \\
\hline & Maize - Gram & 0.43 & 0.18 & 0.20 & 0.37 & 0.34 & 0.13 & 0.14 & 0.54 & 0.31 & 0.15 & 0.06 & 0.42 & 0.24 & 0.10 & 0.20 & 0.32 \\
\hline & Mean & 0.41 & 0.17 & 0.17 & 0.46 & 0.36 & 0.12 & 0.14 & 0.47 & 0.32 & 0.14 & 0.08 & 0.43 & 0.24 & 0.11 & 0.14 & 0.29 \\
\hline \multirow{3}{*}{$\begin{array}{l}\text { LSD }(P \\
<0.05)\end{array}$} & $\mathrm{T}$ & 0.033 & 0.029 & 0.013 & 0.022 & 0.020 & 0.009 & 0.001 & 0.018 & 0.012 & 0.005 & 0.005 & 0.035 & 0.000 & 0.001 & 0.002 & 0.012 \\
\hline & CS & 0.004 & 0.007 & 0.032 & NS & 0.005 & 0.002 & 0.003 & 0.014 & 0.009 & 0.007 & 0.007 & 0.020 & 0.012 & 0.001 & 0.007 & 0.028 \\
\hline & $\mathrm{T} \times \mathrm{CS}$ & 0.013 & NS & 0.040 & 0.037 & 0.022 & 0.004 & 0.015 & 0.041 & 0.015 & 0.015 & 0.010 & NS & 0.012 & 0.008 & NS & 0.022 \\
\hline
\end{tabular}


The soil intensive tillage accelerated SOC decomposition and decrease carbon content by increase organic matter oxidation (Six et al., 1999; Balota et al., 2003; Thomas et al., 2007; Prihar et al., 2016). It is evident from the perusal of data that to bring significant changes in SOC under tillage system it requires a long term continuous residue addition coupled with minimum disturbances in soil. Similarly, NT farming systems usually help to maintain soil organic matter (SOM) and aggregate stability (Rhoton, 2000). The year-round NT management practice was very effective for SOC sequestration in rainfed lentil-finger millet rotation systems. Baker et al., (2007) estimated that the conversion of all croplands to conservation tillage globally could sequester 25 Gt $\mathrm{C}$ over the next 50 years.

\section{Soil organic carbon pools}

The conservation tillage practices had significant effect on soil organic carbon pools (SOCP \%) after third crop cyclein $0-5 \mathrm{~cm}$ depths (Fig. 2). The data showed that the mean value of very labile carbon (VLC) was higher in RT (16.66\%) and NT (14.63\%) than CT system. In general, surface top layer have higher SOC concentration as compared to lower depths. Among the cropping systems (CS) $\mathrm{S}+\mathrm{PP}$ and $\mathrm{M}+\mathrm{PP}$ systems have higher VL $(8.0 \& 20.0 \%)$ and $\mathrm{L}(5.0 \& 33.0 \%)$ carbon at $0-5 \mathrm{~cm}$ depth in $\mathrm{CT}$ as compared to other systems. But, LLC and NLC were highest in $\mathrm{M}-\mathrm{G}$ and $\mathrm{S}+\mathrm{PP}$ systems respectively. In case of reduce tillage (RT) SW system was showed higher VLC (10.0\%) and LC $(51.0 \%)$ in M-G system than NT and CT systems but, LLC and NLC were highest in $\mathrm{M}-\mathrm{G}$ and $\mathrm{S}-\mathrm{W}$ systems in $0-5 \mathrm{~cm}$ depth respectively. The S-W and M-G cropping systems have similar $(6.0 \%)$ very labile fraction in top soil layer. Cropping systems have been showed significant effect on VL, L and LLC fractions, but NLC fraction did not show any significant effect. The interaction between tillage ( $\mathrm{T}$ ) and cropping systems (CS) showed significant difference in labile carbon (LC) fraction in $0-5 \mathrm{~cm}$ depth (Figs. 3-5).

For in depth understanding of carbon pools data, a ratio between (LLC + NLC) and (VLC $+\mathrm{LC})$ was also worked out. Overall, the ratio of (LLC + NLC): (VLC + LC) was more than 1 across tillage system indicating more recalcitrant form carbon exists in the vertisols than easily labile or oxidizable fractions. It was also observed the majority of the differences were found in the most easily oxidizable fraction i.e., very labile form (VLC). This fraction was more labile (more easily decomposable) and for this reason is related to supply of organic residues in the soil (Chan et al., 2001; Chan, 2002), which explains greater differences of this fraction in soils and with increase in depth, greater values in the layer closest to the surface. Similar to our results, Rangel et al., (2008) and Andrade et al., (2005) also observed marked reduction of levels of F1 with increase in depth. Moreover, smaller variation of fractions LC, LLC, and NLC was also observed with increase in depth of the soil, which indicates that these fractions are less sensitive to changes in $\mathrm{C}$ quality across the soil depth. Similarly, results were reported by Chan et al., (2001) who also observed that most differences among pastures occurred in the more easily oxidizable fractions, and only small differences were detected in other fractions.

\section{Acknowledgments}

First author sincerely thanks Dr. S. K. Patil, Vice-Chancellor (IGKV, Raipur Chhattisgarh). Author is also thanks Director (ICAR-Indian Institute of Soil Science) for providing necessary facilities in carrying out this piece of research work. Author is also 
equally indebted and express my heartfelt sense of gratitude to Co-chairman Dr. A.K. Biswas, Head of the Division of Soil Chemistry and Fertility and Advisory Member Dr. J. Somasundaram, Principal Scientist, Division of Soil Physics, ICARIndian Institute of Soil Science, Bhopal (M.P.) for suggesting the problem, providing necessary field and laboratory facilities and for their healthy criticism in preparing the present manuscript of the my thesis to make this task a success. They have been a constant source of inspiration and their love and affection to me will ever be remembered. Thanks are due to all other scientific and field and laboratory supporting staffs are duly acknowledged. The help rendered by Ms. Shamandeep kaur Barar, Senior Research Fellow is heartily acknowledged.

\section{References}

Alvear M, Rosas A, Rouanet JL and Borie F. 2005. Effects of three soil tillage systems on some biological activities in an Ultisol from southern Chile. Soil Till. Res. 82:195-202.

Andrade, C. A., Oliveira, C. and Cerri, C.C. 2005. Qualidade da materiaorganica e estoques de carbon e nitrogenioem Latossolo tratado com biossolidoe cultivado com eucalipto. R Bras. Ci. Solo. 29:803-816.

Balota, E.L., Filho, A.C., Andrade, D.S. and Dick, R.P. 2004. Long-term tillage and crop rotation effects on microbial biomass and $\mathrm{C}$ and $\mathrm{N}$ mineralization in a Brazilian Oxisol. Soil Till. Res. 77: 137-145.

Bayer, C., L. Martin-Neto, J. Mielniczuk, A. Pavinato, and J. Dieckow. 2006. Carbon sequestration in two Brazilian cerrado soils under no-till. Soil Till. Res. 86: 237245.

Benegas, C.P. 1998. Effect of no-tillage system on chemical and physical characteristics of soil in Paraguay. p. 19-28. In M. Kokubun (ed.) No tillage cultivation of soybean and future research needs in
South America. JIRCAS Working Rep. 13. MAFF, Tsukuba, Ibaraki, Japan.

Bhattacharyya R., Kundu S., Pandey S.C., Singh K.P., Gupta H.S., 2008. Tillage and irrigation effects on crop yields and soil properties under the rice-wheat system in the Indian Himalayas. Agril.Water Manag. 95: 993-1002.

Bhattacharyya, R., Das, T.K., Sudhishri, S., Dudwal, B., Sharma, A.R. and Bhatia, A., 2015. Conservation agriculture effects on soil organic carbon accumulation and crop productivity under a rice-wheat cropping system in the western IndoGangetic Plains. Europ. J. Agro. 70: 1121.

Bhattacharyya, R., R.B. Ved-Prakash, S. Kundu, A.K. Srivastva, and H.S. Gupta. 2009. Soil aggregation and organic matter in a sandy clay loam soil of the Indian Himalayas under different tillage and crop regimes. Agric. Ecosyst. Environ. 132: 126-134.

Bhattacharyya, R., Tuti, M.D., Kundu, S., Bisht, J.K. and Bhatt, J.C. 2012. Conservation tillage impacts on soil aggregation and carbon pools in a sandy clay loam soil of the Indian Himalayas. Soil Sci. Soc. Am. J. 76: 1-11.

Bosatta, D.A., Agren, G.I. 1994. Theoretical analysis of microbial biomass dynamics in soils. Soil Biol. Biochem. 26: 143-148.

Burle, M.L., Mielniczuk, J. and Focchi, S. 1997. Effect of cropping systems on soil chemical characteristics, with emphasis on soil acidification. Soil Pl. 190:309316.

Carter, M.R. 1992. Influence of reduced tillage systems on organic-matter, microbial biomass, macro-aggregate distribution and structural stability of the surface soil in a humid climate. Soil Till. Res. 23: 361-372.

Chan, K.Y., Booowman, A. and Oates, A. 2001. Oxidizible organic carbon fractions and soil quality changes in an oxicpaleustalf under different pasture leys. Soil Sci. 166: 61-67.

Chan, K.Y., Heenan, D.P. and Oates, A. 2002. 
Soil carbon fractions and relationship to soil quality under different tillage and stubble management. Soil Till. Res. 63:133-139.

Chen, H., Hou, R., Gong, Y., Li, H., Fan, M. and Kuzyakov, Y. 2009. Effects of 11 years of conservation tillage on soil organic matter fractions in wheat monoculture in Loess Plateau of China. Soil Till. Res. 106: 85-94.

Chen, H.Q., Marhan, S., Billen, N. and Stahr, K. 2009. Soil organic carbon and total nitrogen stocks as affected by different land uses in Baden-Wurttemberg. South West Germany. J. Pl. Nutri. Soil Sci. 172: 32-42.

Cole, C.V., Duxbury, J., Freney, J., Heinemeyer, O., Minami, K., Mosier, A., Paustian, K., Rosenberg, N., Sampson, N., Sauerbeck, D., Zhao, Q. 1997. Global estimates of potential mitigation of greenhouse gas emissions by agriculture. Nutr. Cycl. Agroecosyst. 49: 221-228.

Conant, R. T., Stewart, C. E., Paustian, K., Plante, A. F. and Six, J. 2007.Soil carbon saturation: concept, evidence and evaluation. Biogeochem. 86:19-31.

Dalal, R.C. 1992. Long-term trends in total nitrogen of a Vertisol subjected in zero tillage, nitrogen application and stubble retention. Aust. J. Soil Res. 30: 223-231.

Dalal, R.C., Allen, D.E., Wang, W.J., Reeves, S. and Gibson, I. 2011. Organic carbon and total nitrogen stocks in a Vertisols following 40 years of no-tillage, crop residue retention and nitrogen fertilization. Soil Till. Res. 112:133-139.

Das TK, Bhattacharyya R, Sharma AR, Das S, Saad AA, Pathak H. 2013. Impacts of conservation agriculture on total soil organic carbon retention potential under an irrigated agro-ecosystem of the western Indo-Gangetic Plains. Eur. J. Agron. $51: 34-42$. doi:10.1016/j.eja.2013.07.003.

Diekow, J., Mielniczuk, J., Knicker, H., Bayer, C., Dick, D. P., and Kogel- Knabner, I. 2005. Soil C and N stocks as affected by cropping systems and nitrogen fertilisation in a southern Brazil Acrisol managed under no-tillage for 17 years. Soil Till. Res. 81: 87-95.

Dolan, M. S., Clapp, C. E., Allmaras, R. R., Baker, J. M., and Molina, J. A. E. 2006. Soil organic carbon and nitrogen in a Minnesota soil as related to tillage, residue and nitrogen management. Soil Till. Res. 89: 221-231.

Doran, J.W. 1980. Soil microbial and biochemical changes associated with reduced tillage. Soil Sci. Soc. Am. J. 44: 765-771.

Feller, C., Beare, M.H., 1997. Physical control of soil organic matter dynamics in the tropics. Geoderma. 79: 69-116.

Freibauer, A., Rounsevell, M.D.A., Smith, P. and Verhagen, J. 2004. Carbon sequestration in the agricultural soils of Europe. Geoderma. 122:1-23.

Ghani, A., Dexter, M., Perrott, W.K., 2003. Hot-water extractable carbon in soils: a sensitive measurement for determining impacts of fertilization, grazing and cultivation. Soil Biol. Biochem. 35: 1231-1243.

Gregorich, E.G., Carter, M.R., Angers, D.A., Monreal, C.M., and Ellert, B. H. 1995. Towards a minimum data set to assess soil organic matter quality in agricultural soils. Canad. J. Soil Sci. 74:367-385.

Gregorich, E.G., Drury, C. F. and Baldock, J. A. 2001. Changes in soil carbon under longterm maize in monoculture and legumebased rotation. Canadian J. Soil Sci. 81: $21-31$

Hati, K.M., Chaudhary, R.S., Somasundaram, J., Saha, R., Mohanty, M. and Singh, R.K. 2014. Conservation agriculture and pulses: Impact on soil health. In: Resource Conservation Technology in Pulses: (Eds Ghosh et al., 2014), Published by Scientific Publisher (India). pp. 405-418.

Haynes, R.J., 2000. Labile organic matter as an indicator of organic matter quality in arable and pastoral soils in New Zealand. Soil Biol. Biochem. 32: 211-219.

Lopez-Fando, C., and Pardo, M. T. 2009. The 
Impact of Tillage Systems and Crop Rotations on Carbon Sequestration in Calcic Luvisol of Central Spain. I World Congress on Conservation Agriculture. Madrid, 1-5 October.

McCarty, G. W., Lyssenko, N. N., Starr, J.L. 1998. Short-term changes in soil carbon and nitrogen pools during tillage management transition. Soil Sci. Soc. Am. J. 62:1564-1571.

Mishra, A.K., Aggarwal, P., Bhattacharyya, R., Das, T.K., Sharma, A.R., Singh, R., 2015. Least limiting water range for two conservation agriculture cropping systems in India. Soil Till. Res. 150: 43-56.

Neugschwandtner, R.W., Liebhard, P. Kaul, H. P. Wagentristl, H. 2014. Soil chemical properties as affected by tillage and crop rotation in a long-term field experiment. Plant Soil Environ. 2: 57-62.

Parihar, C. M., Yadav, M. R., Jat, S. L., Singh, A. K., Kumar, B., Pradhan, S., Chakraborty, D., Jat, M. L., Jat, R. K., Saharawat, Y. S. and Yadava, O. P. 2016. Long term effect of conservation agriculture in maize rotations on total organic carbon, physical and biological properties of a sandy loam soil in northwestern Indo Gangetic Plains. Soil Till. Res.161: 116-128.

Rangel, O. J. P., Silva, C. A., Guimaraes, P. T.G., Guimaraes, R.G. 2008. Frac, oesoxidaveis do carbon organico de Latossolo cultivado com cafeeiroem diferent esespacamentos de plantio. Cienciae Agrotecnologia. 32:429-437.

Rhoton, F. E. 2000. Influence of time on soil response to no-till Practices. Soil Sci. Soc. Am. J. 64:700-709.

Seki, Y., Hoshiba, K. and Bordon. J. 2001. Root distribution of soybean plants in notillage fields in Yguazu District of Paraguay. Jpn. J. Trop. Agric. 45:33- 37.

Sisti, C. P. J., dos Santos, H. P., Kohhann, R., Alves, B. J. R., Urquiaga, S., and Boddey, R. M. 2004. Change in carbon and nitrogen stocks in soil under 13 years of conventional or zero tillage in southern Brazil. Soil Till. Res. 76: 39-58.

Six, J., E. T. Elliott, K. Paustian, and J. W. Doran. 1999. Aggregation and soil organic matter accumulation in cultivated and native grassland soils. Soil Sci. Soc. Am. J. 62:1367-1376.

Thomas, G. A., Dalal, R. C., and Stanley, J. 2007. No-till effects on organic matter, $\mathrm{pH}$, cation exchange capacity and nutrient distribution in a Luvisol in the semi-arid subtropics. Soil till Res. 94:295-304.

Walkley, A. 1947. A critical examination of a rapid method for determining organic carbon in soils: Effect of variations in digestion conditions and inorganic soil constituents. Soil Sci. 63:251-263.

Walkley, A. and Black, I. A. 1934. An examination of the digested method for determining soil organic matter and a proposed modification of the chromic acid titration method. Soil Sci. 37:29-38.

West, T. O., and Post, W. M. 2002. Soil organic carbon sequestration rates by tillage and crop rotation. Soil Sci. Soc. Am. J. 66: 1930-1946.

Zanatta, J. A., Bayer, C., Dieckow, J., Vieira, F. C. B. and Mielniczuk, J. 2007. Soil organic carbon accumulation and carbon costs related to tillage, cropping systems and nitrogen fertilization in a subtropical Acrisol. Soil and Till. Res. 94:510-519.

\section{How to cite this article:}

Awanish Kumar, Anusuiya Panda, V.N. Mishra and Srivastava, L.K. 2018. Short-Term Effect of Conservation Tillage on Carbon Pools under Rainfed Cropping Systems of Central India. Int.J.Curr.Microbiol.App.Sci. 7(01): 2040-2053. doi: https://doi.org/10.20546/ijcmas.2018.701.246 